論文・Paper

\title{
Voltage-Current-Time Characteristic of Stabilized Zirconia with Point Contact Platinum Electrode in Argon Gas Ambient
}

\author{
By \\ Hiroaki YANAGIDA and Takayoshi KANDACHI** \\ (Department of Industrial Chemistry, Faculty of Engineering, University of Tokyo)
}

\section{Introduction}

The voltage-current characteristic of stabilized zirconia is very difficult to define. It changes with temperature, oxygen partial pressure, time and character of electrodes ${ }^{1) \sim 6)}$. It is known that the voltage-current characteristic is more of non-linear behavior under low oxygen partial pressure and with thick electrode. Current decreases with time under low applied field, while it increases with time under high applied field. The decrease is considered to be due to ionic polarization and the increase is due to injection of electrons into solid electrolyte. Although those sort of facts are known, the time dependence has not been main subject of investigation yet. The present work was undertaken to pay special attention to the time dependence. As a start of the work, point contact platinum electrodes, dry argon gas ambient and high applied voltage were chosen.

\section{Experimental}

The specimen used in the present work was with composition $\mathrm{Ca}_{0.12} \mathrm{Mg}_{0.03} \mathrm{Zr}_{0.85} \mathrm{O}_{1.85}$. The density was $93.5 \sim 94 \%$ to theoretical density. Pellets were made in the dimension $10 \mathrm{~mm}$ diameter and $2 \mathrm{~mm}$ thick cut from a sintered rod to avoid trouble arising from difference in sintering condition. Electrodes were platinum wire pressed onto the pellet by spring. The area of the point contact electrode was estimated by measuring a.c. conductivity before d.c. experiments. The area was around $0.0015 \mathrm{~cm}^{2}$. Measurements were done in the temperature range of $480 \sim 650^{\circ} \mathrm{C}$ under dry $\mathrm{Ar}$ gas ambient in sealed $\mathrm{SiO}_{2}$ tube, where oxygen contamination was eliminated by heated spongy titanium as shown

* Partly reported at the 77 th annual meeting of the American Ceramic Society. May 3-8, 1975, Washington D.C. No. 48-E-75.

** Now with Matsuzaka Factory, Central Glass Co. Matsuzaka-city Mie, Japan. in Fig. 1.

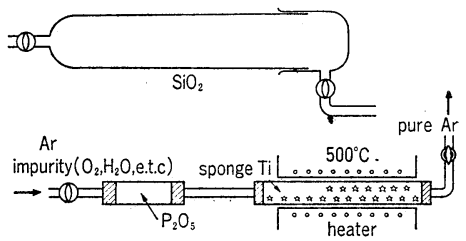

Fig. 1. Atmospheric control system.

D.C. power supply was model $725 \mathrm{C}$ of Kikusui electronic Co. Standard resistance of $100 \mathrm{ohm}$ was put in series in the measuring circuit to prevent the power supply from breakdown and to measure the current through the specimen from the potential drop across the resistance. Applied voltage across the specimen was in the range of 20 to 90 volts. The experimental set-up is schematically shown in Fig. 2.

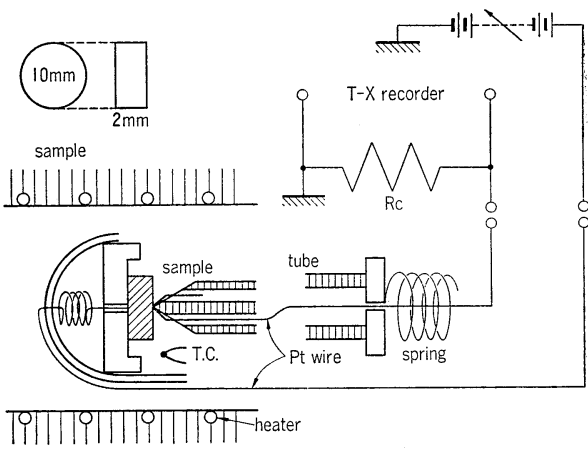

Fig. 2. Experimental set up of the measurement. T.C. : Thermocouple Tube : $\mathrm{Al}_{2} \mathrm{O}_{3}$ Rc : Standard resistance $100 \mathrm{ohm}$

\section{Results and Discussion}

The first stage of the time dependence of the current is as shown in Fig. 3. The time depend-ence is expressed by 


$$
I=c t^{\alpha} \text { or } \frac{\mathrm{d} I}{\mathrm{~d} t}=c \alpha t^{\alpha-1}
$$

where $\alpha$ was found independent of applied voltage and the value being 0.06 as summarized in Table 1. The transition to the second stage of time dependence was very distinct as is shown in Fig. 3.

Table 1. Characteristic values of the first stage of the current-time relation and transition point to the second stage.

\begin{tabular}{|c|c|c|c|c|}
\hline $\begin{array}{l}\text { Tempera- } \\
\text { ture } \\
\text { ('C) }\end{array}$ & $\begin{array}{l}\text { Applied } \\
\text { voltage } \\
\text { (volts) }\end{array}$ & $\alpha$ & $\begin{array}{l}\text { Transition } \\
\text { point } \\
\text { (seconds) }\end{array}$ & $\begin{array}{l}\text { The total } \\
\text { current to } \\
\text { the point } \\
\text { (coulombs) }\end{array}$ \\
\hline ' & 20 & $7.2 \times 10^{-2}$ & 345 & $5.3 \times 10^{-2}$ \\
\hline \multirow[t]{3}{*}{$650^{\circ} \mathrm{C}$} & 30 & $7.2 \times 10^{-2}$ & 213 & $7.8 \times 10^{-2}$ \\
\hline & 50 & $7.2 \times 10^{-2}$ & 66 & $7.4 \times 10^{-2}$ \\
\hline & 30 & $6.5 \times 10^{-2}$ & 810 & $11.3 \times 10^{-2}$ \\
\hline \multirow[t]{3}{*}{$580^{\circ} \mathrm{C}$} & 50 & $6.5 \times 10^{-2}$ & 300 & $7.2 \times 10^{-2}$ \\
\hline & 70 & $6.5 \times 10^{-2}$ & 270 & $8.7 \times 10^{-2}$ \\
\hline & 50 & $5.6 \times 10^{-2}$ & 1704 & $4.6 \times 10^{-2}$ \\
\hline \multirow[t]{2}{*}{$480^{\circ} \mathrm{C}$} & 70 & $5.4 \times 10^{-2}$ & 1050 & $3.4 \times 10^{-2}$ \\
\hline & 90 & $5.5 \times 10^{-2}$ & 870 & $3.4 \times 10^{-2}$ \\
\hline
\end{tabular}

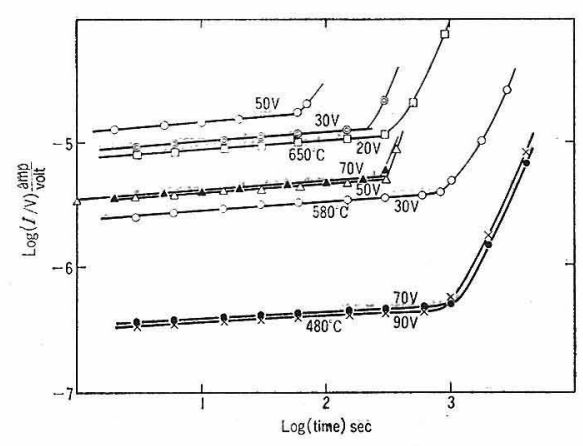

Fig. 3. The first stage of the current-time characteristic. Knicks in the figure are the transition point to the second stage of characteristic.

For example at $480^{\circ} \mathrm{C}$ the point is $870 \mathrm{sec}$ under the applied of 90 volts. The values of $\alpha$, the transition point to the second stage and the total current up to the point are summarized in Table 1. In the second stage the characteristic is given by

$\ln I=k t$ or $\mathrm{d} I / \mathrm{d} t=k I$

as is shown in Fig. 4, where $I$ denotes the total current, $k$ constant and $t$ time. The rapid increase was seen in the last stage. This stage was of breakdown. The cross section and color of the specimens at the stages are shown in Fig 5. At the first stage the colored part developed from the cathode. And the point at which the colored part reached the anode was the transition point to the second stage. The specimen exposed to breakdown had a very dark core in the center of the colored part.

The electrical conductivity of the first stage was plotted against reciprocal temperature as in Fig 6 . The Arrhenius. value was in the range of $1.17 \sim$

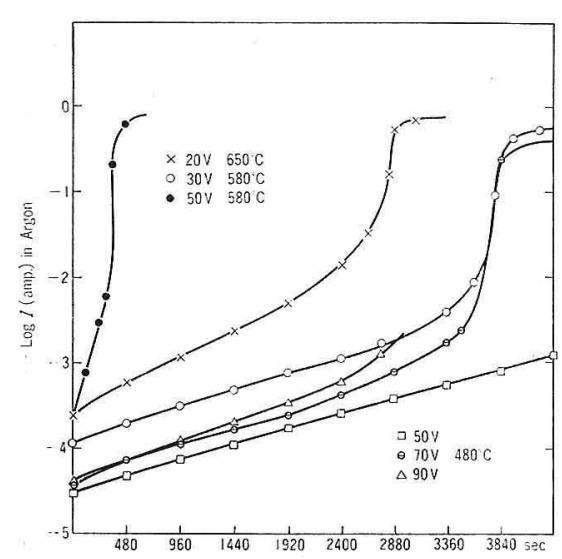

Fig. 4. The second stage of the current-time characteristic.

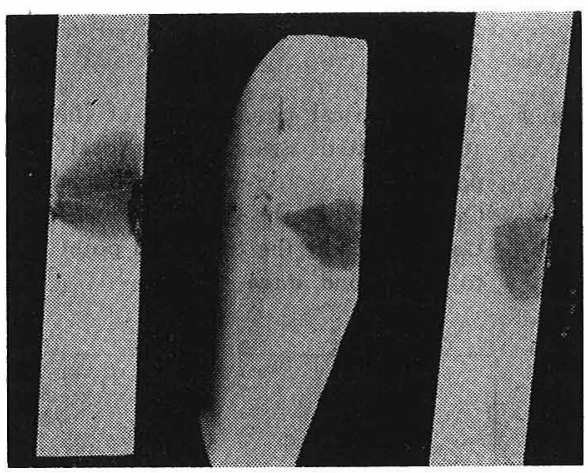

Fig. 5. The cross section and color of the specimen at various stages.

The right : First stage

The middle : The transition point The left : Second stage

$1.21 \mathrm{eV}$ which was very close to the value of a.c. ionic conductivity. The time required for the transition to the second stage plotted against reciprocal temperature also gave the Arrhenius value very close to the value of a.c. ionic conductivity.' This shows that at the first stage the electric current is mostly ionic. The Arrhenius plot of a.c. conductivity of the end of the second stage is shown in Fig 7. The Arrhenius value is far less than that of ionic conduction. The electric conduction of the colored part in this stage was not ionic but may be electronic. Partial reoxidation was recognized for the specimen kept in Ar gas for $2 \mathrm{~h}$. The Arrhenius value increased and approached to the value for ionic conduction. There is no indication of segregation of zirconium metal in the colored region, however. Any X-ray diffraction pattern arising from crystals other than stabilized zirconia was not detected. Difference in lattice dimension of the phase between colored and uncolored parts was not detected either. The range of applied voltage as high as $20 \sim 90 \mathrm{~V}$ in the present experiment made 


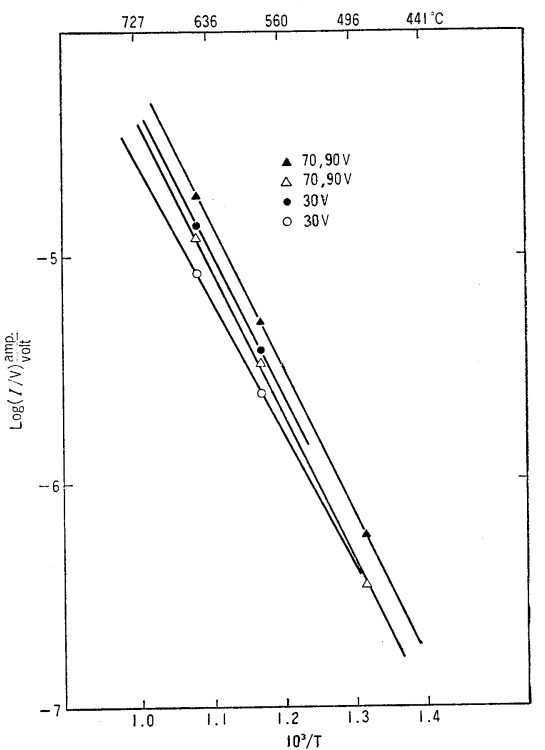

Fig. 6. The flectrical conductivity of the first stage plotted against reciprocal temperature.

Open mark : at the starting point Dark mark : at the transition point to the second stage

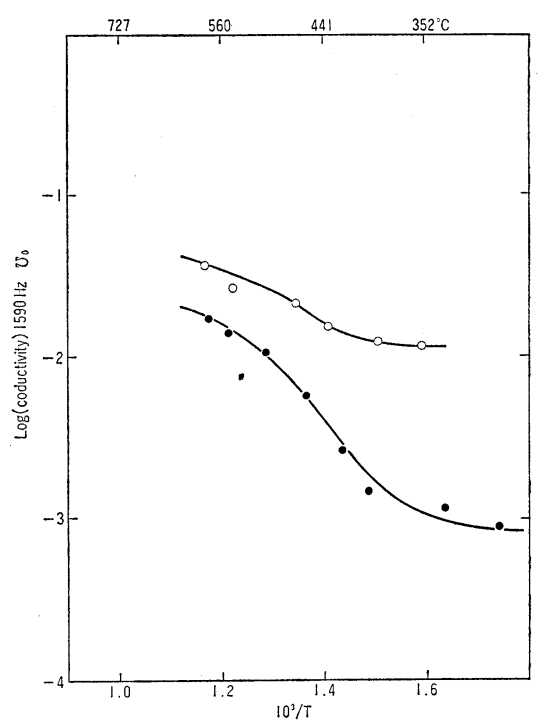

Fig. 7. The electrical conductivity at the end of second stage plotted against reciprocal temperature.

Open Mark; measurred immediately after the interrupting the d.c. high field.

Dark mark; value for the specimen kept in $\mathrm{Ar}$ gas for $2 \mathrm{~h}$ after the interruption.

possible minimizing contribution of supply of oxygen from ambient through platinum electrode (cathode) if compared with polarizing effect across the elec: trolyte. In the first stage of current-time characteristic oxygen ions were removed from cathode side to anode side. The current in this stage was. ionic. Depletion of slight amount of oxygen ions. at the cathode side gave rise to the colored part developing from the cathode. The total current up to the transition point of the characteristic to the second stage was in the range between 0.034 and 0.113 coulombs through the colored part. Distinct boundary between colored and uncolored parts. made possible estimation of the volume of the colored part; the value estimated being in the range of $0.0003 \sim 0.0010 \mathrm{~cm}^{3}$. Thus at he transition point the concentration of injected electrons. was around $1.2 \times 10^{2}$ coulombs $/ \mathrm{cm}^{3 *}$. On the other hand the concentration of oxygen vacancies is around $1.77 \times 10^{6}$ coulombs $/ \mathrm{cm}^{3}$ from the chemical composition of the stabilized zirconia of $\mathrm{Ca}_{0.12}$. $\mathrm{Mg}_{0.03} \mathrm{Zr}_{0.85} \mathrm{O}_{1.85}$, and density, where oxygen vacancies was $2.00-1.85=0.15$ in the formula. The ratio of concentration of electrons injected into oxygen vacancies to that of oxygen vacancies is only $0.656 \times 10^{-4}$. This small amount of electrons gave rise to the color. The a.c. conductivity at the transition point consisted of ionic and electronic conductivities, which was to be nearly equal, since the total conductivity in the first stage increased by a factor of 1.62 between the starting point and the transition point as seen in Figs. 3 and 6 . The ionic conductivity at $580^{\circ} \mathrm{C}$ of the specimen used in the present experiment was $3 \times 10^{-4} \mathrm{ohm}^{-1} \cdot \mathrm{cm}^{-1}$. Electron mobility is thus calculated to be $\mu=1.6 \times 10^{-6}$ $\mathrm{cm}^{2} / \mathrm{V} \cdot \mathrm{sec}^{* *}$. The order of the value suggests that the electronic conduction in the colored part is bue to a dopping mechanism. The mobility of oxygen vacancies is calculated in the same way*** as $1.7 \times 10^{-10} \mathrm{~cm}^{2} / \mathrm{V} \cdot \mathrm{sec}$. In the second stage of current-time characteristic oxygen ions were still removed from the electrolyte. Electrons were injected by the amount of removed oxygen atoms. Electrons thus injected increased the total conductivities. If the effective area of the electrode was kept constant the current-time characteristic shoud

* The concentration was calculated as (the total current=injected electrons)/(the volume of colored part).

** At the transition point, the conductivity due to electronic current $\left(\sigma_{\mathrm{e}}\right)$ was $1.9 \times 10^{-4} \mathrm{ohm}^{-1} \cdot \mathrm{cm}^{-1}$ and the electron concentration $\left(n_{\mathrm{e}} \mathrm{e}\right)$ was $1.2 \times 10^{2}$ coulombs $/ \mathrm{cm}^{s}$. The mobility $\left(\mu_{\mathrm{e}}\right)$ was thus calculated by the equation $\left(\sigma_{\mathrm{e}}=n_{\mathrm{e}} \mathrm{e} \mu_{\mathrm{e}}\right.$, where $\mathrm{e}$ iselectronic charge of an electron.

*** Here the relation $\sigma_{\mathrm{v}}=2 n_{\mathrm{v}} \mathrm{e} \mu_{\mathrm{v}}$ is used. The ionic conductivity $\sigma_{v}$ is $3 \times 10^{-4} \mathrm{ohm}^{-1} \cdot \mathrm{cm}^{-1}$ and the density of oxygen vacancies $2 n_{\mathrm{v}} \mathrm{e}$ is $1.77 \times 10^{6}$ coulombs $/ \mathrm{cm}^{3}$ as mentioned above. Thus the mobility of oxygen vacancies is given as $1.7 \times$ $10^{-10} \mathrm{~cm}^{2} / \mathrm{V} \cdot \mathrm{sec}$. 
be linear. The characteristic observed was logarithmic, however. This means that electrons diffused from the core of the colored conduction path increased the effective cross section of the conduction path. There was a gradient of electron concentration across the cross section. The second stage time-current characteristic was, therefore, given as $\mathrm{d} I / \mathrm{d} t=k I$. The current was proportional to the total amount of injected electrons indicating the current of electronic behavior. The breakdown arose from the more reduction of the core of the colored conduction path.

\section{Summary}

Voltage-current-time characteristic of stabilized zirconia with point contact platinum electrode was investigated in the temperature range of $480 \sim 650^{\circ} \mathrm{C}$ under Ar gas ambient. The applied voltage was chosen higher than 20 volts to give rise to deep polarization across the specimen. The current-time characteristic consisted of three stages. In the first stage of the characteristic the current increased slowly. Colored part gradually developed from cathode to anode. In this stage the ionic current predominated over the electronic current. The point at which the front of the colored part reached the anode was a transition to the second stage of characteristic, in which the rate of current increase was proportional to the current itself, where the current was of electronic behavior. Electrons thus injected were of the mobility by the order of $2 \times$ $10^{-6} \mathrm{~cm}^{2} / \mathrm{V} \cdot \mathrm{sec}$ at $580^{\circ} \mathrm{C}$ indicating hopping mechanism. Finally the breakdown took place. The color arose from injection of electrons from cathode.

\section{References}

1) R.W. Vest and N.M. Tallan, J. Appl. Phys. 36 [2] 543 (1965).

2) L. Heyne, "Ionic Conductivity in Oxides", p. 149 -64 of "Mass Transport in Oxides", J. B. Wachtman, Editor, National Bureau of Standard, Special Publication No. 296 (1968).

3) M. Kleitz, "Electrode Reactions in Solid Oxide Electrolytes" Thesis, University of Grenoble (May, 1968).

4) D. Yuan and F.A. Kroger, J. Electrochem. Soc. 116 [5] 594 (1969).

5) H. Yanagida, R.J. Brook and F.A. Kroger, J. Electrochem. Soc. 117 [5] 593 (1970).

6) R.J. Brook, W.L. Pelzmann and F.A. Kroger, J. Electrochem. Soc. 118 [2] 185 (1971).

[Received October 30, 1975]

\section{白金点電極アルゴン雾囲気中での安定化ジルコニアの 電圧一電流一時間特性}

\section{柳 田 博 明・神 立 孝 良 (東京大学 工学部 工業化学科)}

安定化ジルコニアの電圧一電流一時間特 性を 480〜 $650^{\circ} \mathrm{C}$ アルゴン雾囲気中で，白金点電極を用いて測定し た．用いた電圧は 20９0 ボルトであり，白金電極を通 して酸素の供給量が，ジルコニア試料中の酸素イオン移 動量よりはるかに少ないといら条件を満たす。電流一時 間特性は 3 段階にわかれている．第 1 段階は，爫るやか な電流増加であり, 着色部分がカソード部から成長して いる.着色部の先端がアノードに到着した点が第 2 段階
への転移点である. 第 1 段階での電流はイオン電流で ある. 第 2 段階での電流増加率は電流 值 自 身に比例す る.この段階での電流は電子電流であり, 電子の易動度 は $1.6 \times 10^{-6} \mathrm{~cm}^{2} / \mathrm{V} \cdot \sec \left(580^{\circ} \mathrm{C}\right)$ と算定された. 第 3 段 階は絶縁破壊であり，着色した導電径路の芯の着色が濃 くなるが，金属ジルコニウムの析出は認められなかっ た。

(10/30/1975 受付) 